\title{
Betazole Hydrochloride
}

National Cancer Institute

\section{Source}

National Cancer Institute. Betazole Hydrochloride. NCI Thesaurus. Code C65259.

The hydrochloride salt form of betazole, a histamine $\mathrm{H} 2$ receptor agonist with diagnostic application. Betazole selectively targets and binds to the $\mathrm{H} 2$ receptor, thereby mimicking the effect of histamine on these receptors. This may lead to an increase in gastric secretions. Betazole can be used in gastric function tests. 